\title{
IDENTIFIKASI MISKONSEPSI MATERI JARINGAN TUMBUHAN PADA MAHASISWA PENDIDIKAN BIOLOGI DI SALAH SATU UNIVERSITAS DI SURAKARTA
}

\author{
Yeni Puspitasari $^{1}$ \\ Salsabiela Praha Karima Reza ${ }^{2}$ \\ Yusuf Bachtiar ${ }^{3}$ \\ Baskoro Adi Prayitno 4 \\ $1,2,3,4$ \\ Program Studi Pendidikan Biologi, FKIP, Universitas Sebelas Maret \\ E-mail: ${ }^{1}$ yenipuspitasari1802@ student.uns.ac.id, ${ }^{2}$ salsabielapraha@ student.uns.ac.id, ${ }^{3}$ yusufbach@ \\ student.uns.ac.id, baskoro_ap@fkip,ins.ac.id
}

\begin{abstract}
Misconception in learning biology is still a major problem and has become one of the focus points of research in the field of education in recent years. Misconceptions can occur at various levels of education. In the study of misconceptions the target of the study was mostly high school students and yet misconception research was rarely carried out on college students. This study aims to determine the level of misconceptions of biology education students at one of the universities in Surakarta and to know the difference in the level of misconceptions in upper and lower academic ability students. The population of this study was all semester 2 Biology Bachelor education students at one of the universities in Surakarta totaling 63 students. The sampling technique uses saturated sampling by using the entire population as a research sample. The level of misconceptions is measured using a misunderstanding test that is equipped with a CRI index. Data analysis to determine the level of misconceptions of students as well as differences in levels of misunderstanding of students above and below was done by quantitative descriptive analysis. The results showed students know the concept as much as 33.45\%, do not know the concept as much as $41.9 \%$ and student misconceptions as much as $24.63 \%$. The percentage of students' misconceptions is spread across each indicator of the problem being tested. The biggest misconception occurred in the structure and function indicators of various plant tissues $46.51 \%$, indicators of the types and structure of plant tissue cells $40.93 \%$, basic principle indicators of tissue culture $5.12 \%$ and indicators of tissue structure in Plants $0.93 \%$. Based on the student category, the percentage of students from the top category had a misunderstanding of $28.37 \%$, the medium category was $52.55 \%$ and the lower category was $19.07 \%$
\end{abstract}

Kata kunci: CRI (Certainty of Response indeks), Miskonsepsi, Jaringan Tumbuhan

\section{PENDAHULUAN}

Proses penerimaan materi pembelajaran oleh siswa tidak sama satu sama lain. Siswa memiliki pemahaman yang berbeda dari apa yang dibaca dan didengar. Perbedaan persepsi dari masingmasing siswa menimbulkan istilah belum memahami konsep atau materi, memahami konsep atau materi, dan salah memahami konsep atau materi.
Kesalahan memahami konsep atau materi yang diterima oleh siswa disebut dengan istilah miskonsepsi. Miskonsepsi merupakan keadaan dimana pemahaman seseorang mengenai suatu konsep tidak sesuai dengan teori ilmiah (Ross dkk., 2006). Penyebab terjadinya miskonsepsi berasal dari beberapa sumber yaitu dari dalam diri siswa sendiri, guru, buku teks pelajaran yang digunakan, konteks dan 
cara yang digunakan guru dalam mengajar (Suparno, 2013).

Miskonsepsi dalam pembelajaran banyak terjadi baik dikalangan SD, SMP, SMA sampai Perguruan Tinggi. Miskonsepsi akan menghambat proses asimilasi pengetahuan baru dalam diri siswa, sehingga akan berdampak pada keberhasilan siswa dalam proses pembelajaran selanjutnya. Hal tersebut diperkuat bahwa miskonsepsi berbahaya sebab akan memberikan pemikiran dan rasa yang salah dalam memahami konsep sehingga membatasi usaha belajar dan terjadi hambatan pemahaman dan pengembangan antara konsep sebelumnya yang salah dengan konsep baru yang sedang dipelajari (Muntiani, 2015). Pengetahuan awal siswa terhadap konsep awal yang keliru, atau konsep yang benar namun dalam menghubungkan pada konsep selanjutnya yang salah menjadi dasar terjadinya miskonsepsi (Kusumaningrum, 2014).

Miskonsepsi banyak terjadi dalam berbagai materi pembelajaran salah satunya adalah materi biologi. Miskonsepsi dalam pembelajaran biologi masih menjadi masalah utama dan menjadi salah satu titik fokus penelitian pada bidang pendidikan beberapa tahun terakhir.

Biologi adalah salah satu mata pelajaran Ilmu Pengetahuan Alam serta mata pelajaran pilihan untuk Sekolah Menengah Atas berdasarkan kurikulum 2013. Pembelajaran biologi lebih mengutamakan pada pengalaman secara langsung sehingga dapat dikembangkan sesuai dengan kompetensi siswa dalam memahami alam sekitar secara ilmiah. Pembelajaran biologi bertujuan membuat siswa mampu memahami konsep-konsep biologi, mampu mengaitkan satu konsep dengan konsep yang lain, dan mampu memecahkan masalah dalam kehidupan sehari-hari. Apabila pemahaman konsep terhadap materi kuat, siswa akan mampu memahami serta mengembangkan konsep lebih tinggi. Perlunya pemahaman konsep dasar disebabkan karena dalam pembelajaran, setiap konsep yang satu berhubungan dengan konsep lainnya. Dimana sebuah konsep merupakan hal yang sangat penting sebagai landasan berpikir (Dahar, 2011). Sebagai contoh pemahaman konsep dalam materi klasifikasi hewan dimana semua beranggapan bahwa hewan mamalia selalu bereproduksi dengan melahirkan (vivipar) namun dalam konsep terdapat pengecualian bahwa pada hewan Platipus yang tergolong sebagai mamalia memiliki cara reproduksi dengan bertelur (ovipar). Kesulitan yang terjadi dalam materi biologi sehingga menyebabkan terjadi miskonsepsi dapat berasal dari istilah asing dalam biologi yang belum dapat diterima dan dikuasi serta kerumitan dari suatu konsep disebabkan oleh kompleksitas informasi atau ciri yang membentuk suatu konsep tersebut.

Beberapa penelitian mengenai miskonsepsi pada pembelajaran biologi telah dilakukan salah satunya mengenai materi fotosintesis dan respirasi tumbuhan yang menunjukkan angka miskosepsi 37,99\% (Mustaqim dkk., 2014), sedangkan pada materi sistem reproduksi manusia kelas XI IPA SMA Ali Hasjmy ditemukan miskonsepsi sebanyak 32,27\% (Ramadhani dkk., 2016). Beberapa hasil penelitian menunjukkan miskonsepsi pada sejumlah konsep biologi lain diantaranya adalah konsep struktur tubuh manusia, evolusi, genetika, serta bioteknologi. 
Miskonsepsi juga ditemukan oleh Murni (2013) pada konsep struktur dan fungsi sel, struktur tumbuhan dan sistem koordinasi. Konsep struktur dan fungsi jaringan tumbuhan adalah salah satu materi yang sulit dipahami disebabkan banyaknya istilah ilmiah yang abstrak dan banyak konsep yang harus dihafal. Hal tersebut sejalan dengan penelitian yang dilakukan di MAN 10 Jakarta bahwa terjadi miskonsepsi pada konsep jaringan tumbuhan. Sedangkan penelitian yang dilakukan oleh Gumilang (2017) menunjukkan adanya miskonsepsi materi jaringan tumbuhan sebesar 20,19\% pada siswa kelas XI IPA SMAN 1 Depok.

Miskonsepsi yang terjadi pada siswa harus diketahui penyebabnya sehingga perlu adanya identifikasi untuk mengurangi terjadinya miskonsepsi. Salah satu teknik yang dapat digunakan untuk mengidentifikasi miskonsepsi adalah memberikan tes miskonsepsi yang dapat berupa tes pilihan ganda (multiple choiche) Gumilang (2017). Perbedaan siswa yang belum memahami konsep, memahami konsep dan miskonsepsi dapat diukur dengan metode CRI ( Certainty of Response Index) yang ditemukan oleh Saleem Hasan. Metode ini digunakan dengan mengukur tingkat keyakinan sampel terhadap jawaban yang diberikan pada setiap soal.

Penelitian miskonsepsi pada materi biologi banyak dilakukan di siswa berjenjang SMA, oleh sebab itu peneliti tertarik mengetahui tingkat miskonsepsi materi biologi pada konsep jaringan tumbuhan yang terjadi pada mahasiswa Perguruan Tinggi khususnya pendidikan biologi di salah satu Universitas di Surakarta.

\section{METODE}

Penelitian dilaksanakan pada mahasiswa pendidikan biologi semester 2 di salah satu universitas di Surakarta pada tanggal 20 Mei 2019 sampai dengan 27 Mei 2019 dengan metode survei. Subjek dalam penelitian ini adalah seluruh mahasiswa pendidikan biologi yang berjumlah 63 mahasiswa. Sampel ditentukan berdasarkan teknik sampling jenuh. Berdasarkan kesediaan sampel terdapat 15 mahasiswa tidak bersedia, sehingga total sampel yang digunakan hanya 48 mahasiswa.

Prosedur pengambilan data dilakukan dengan memberikan Instrumen tes miskonsepsi berupa soal pilihan gandal atau multiple choice berjumlah 17 butir soal yang terdiri dari beberapa indikator yaitu membedakan struktur jaringan berdasarkan gambar, identifikasi jaringan tumbuhan berdasarkan macam dan struktur sel penyusunnya, membedakan struktur dan fungsi berbagai jaringan (epidermis, kolenkim, sklerenkim, parenkim, xilem, floem, dan kambium) penyusun organ tumbuhan, dan mendeskripsikan prinsip dasar kultur jaringan diperoleh dengan dilengkapi Certainty of Response Index (CRI) yang dikembangkan oleh Gumilang (2017). Waktu pengerjaan soal selama 50 menit.

Analisis data yang digunakan dalam penelitian ini adalah menggunakan deskriptif kuantitatif. Dengan ketentuan pengukuran tingkat keyakinan responden terhadap jawaban pertanyaan yang diberikan. Tingkat keyakinan tersebut diketahui menggunakan skala yang digunakan dalam CRI setiap soal. Skala dalam 
CRI memiliki nilai yang berbeda tergantung pada masing-masing kriteria ( tabel 1)

Tabel 1. Kriteria skala CRI

\begin{tabular}{|c|c|}
\hline $\begin{array}{c}\text { Skala } \\
\text { CRI }\end{array}$ & Kriteria \\
\hline 0 & $\begin{array}{l}\text { Jika menjawab soal dengan } \\
\text { persentase unsur tebakan } 100 \% . \\
\text { hanya menebak (Total guess the } \\
\text { answer) }\end{array}$ \\
\hline 1 & $\begin{array}{l}\text { Jika menjawab soal dengan } \\
\text { presentase unsur tebakan antara } 75- \\
99 \% \text { lebih banyak menebak } \\
\text { (Almost guest) }\end{array}$ \\
\hline 2 & $\begin{array}{l}\text { Jika menjawab soal dengan } \\
\text { presentase unsur tebakan antara } 50 \text { - } \\
74 \% \text { Tidak Yakin } \\
\text { ( Not sure) }\end{array}$ \\
\hline 3 & $\begin{array}{l}\text { Jika menjawab soal dengan } \\
\text { presentase unsur tebakan antara } 25- \\
49 \% \text { Yakin (sure) }\end{array}$ \\
\hline 4 & $\begin{array}{l}\text { Jika menjawab soal dengan } \\
\text { presentase unsur tebakan antara } 1 \text { - } \\
24 \% \text { Hampir yakin tanpa } \\
\text { keraguan (Almost certain) }\end{array}$ \\
\hline 5 & $\begin{array}{l}\text { Jika menjawab soal dengan } \\
\text { presentase unsur tebakan } 0 \% \\
\text { Sangat Yakin (certain) }\end{array}$ \\
\hline
\end{tabular}

(Qurrota \& Nuswowati, 2018)

Penetapan mahasiswa termasuk dalam kriteria kelompok Miskonsepsi (Mk), tidak tahu konsep (TTK), dan tahu konsep (TK) digunakan kriteria seperti dalam Tabel ii.

Tabel 2. Penetapan kelompok konsepsi siswa

\begin{tabular}{cll}
\hline Analisis & $\begin{array}{c}\text { Indeks CRI } \\
\text { Rendah } \\
(<\mathbf{2 , 5})\end{array}$ & $\begin{array}{c}\text { Indeks CRI Tinggi } \\
(>\mathbf{2 , 5})\end{array}$ \\
\hline 1 & & \\
\hline & Jawaban benar & Jawaban benar dan \\
tetapi indeks & CRI tinggi berarti \\
& CRI rendah \\
berarti tidak & tahu konsep (TK) \\
& tahu konsep & \\
& (TTK) & \\
& &
\end{tabular}

\begin{tabular}{lll}
\hline 2 & Jawaban salah & Jawaban salah \\
dan CRI & tetapi CRI tinggi \\
& rendah berarti & berarti miskonsepsi \\
& tidak tahu & $(\mathrm{Mk})$ \\
& konsep (TTK) &
\end{tabular}

(Qurrota \& Nuswowati, 2018)

\section{HASIL}

Miskonsepsi secara Umum

Tabel 3. Tingkat konsepsi mahasiswa pendidikan biologi

\begin{tabular}{ll}
\hline $\begin{array}{l}\text { Konsepsi } \\
\text { Mahasiswa }\end{array}$ & Presentase \\
\hline $\begin{array}{l}\text { Tidak Tahu Konsep } \\
\text { (TTK) }\end{array}$ & $43,62 \%$ \\
\hline Tahu Konsep (TK) & $30,02 \%$ \\
\hline Miskonsepsi (Mk) & $26,34 \%$ \\
\hline
\end{tabular}

Berdasakan Tabel 3, Miskonsepsi berada pada tingkat terendah dari ketiga katogeri konsepsi mahasiswa lainya yaitu pada presentase $26,34 \%$. Selain itu pemahaman siswa terhadap konsep jaringan tumbuhan berada pada peringat ke-2 dengan presentase 30,02\%. Pada ketidaktahuan mahasiswa terhadap konsep jaringan tumbuhan berada pada peringkat pertama dengan presentase $43,62 \%$.

\section{Miskonsepsi berdasarkan Indikator Materi}

Tabel 4. Presentase tingkat konsepsi mahasiswa pada indikator yang diteliti

\begin{tabular}{llll}
\hline \multirow{2}{*}{ Indikator } & \multicolumn{2}{c}{ Konsepsi Mahasiswa } \\
\cline { 2 - 4 } & & & \\
\cline { 2 - 4 } & TTK & TK & Mk \\
\hline $\begin{array}{l}\text { Membedakan } \\
\text { struktur jaringan } \\
\text { pada tumbuhan } \\
\text { menggunakan }\end{array}$ & $4,21 \%$ & $12,65 \%$ & 0,93 \\
gambar & & & $\%$ \\
\hline $\begin{array}{l}\text { Mengidentifikasi } \\
\text { jaringan tumbuhan }\end{array}$ & $36 \%$ & $48,97 \%$ & 40,93 \\
\hline
\end{tabular}




\begin{tabular}{|c|c|c|c|}
\hline $\begin{array}{l}\text { berdasarkan } \\
\text { macam dan struktur } \\
\text { sel penyusunnya }\end{array}$ & & & \\
\hline $\begin{array}{l}\text { Membedakan } \\
\text { struktur dan } \\
\text { fungsi berbagai } \\
\text { jaringan } \\
\text { (epidermis, } \\
\text { kolenkim, } \\
\text { sklerenkim, } \\
\text { parenkim, } \\
\text { xilem, floem, } \\
\text { dan kambium) } \\
\text { penyusun organ } \\
\text { tumbuhan }\end{array}$ & $46,35 \%$ & $48,57 \%$ & $\begin{array}{l}46,51 \\
\%\end{array}$ \\
\hline $\begin{array}{l}\text { Mendeskripsikan } \\
\text { prinsip dasar kultur } \\
\text { jaringan }\end{array}$ & $9,55 \%$ & $1,22 \%$ & $\begin{array}{l}5,12 \\
\%\end{array}$ \\
\hline
\end{tabular}

Dari hasil tabel 4 dapat diketahui tingkat konsepsi mahasiswa khususnya miskonsepsi terhadap materi jaringan tumbuhan tiap indikator yang diteliti. Miskonsepsi terendah terjadi pada indikator pemahaman mahasiswa membedakan struktur jaringan berdasarkan gambar dengan presentase sebesar $0,93 \%$, selanjutnya indikator mendeskripsikan prinsip dasar kultur jaringan diperoleh presentase miskonsepsi mahasiswa sebanyak $5,12 \%$, posisi ketiga terjadi pada indikator mengenai identifikasi jaringan tumbuhan berdasarkan macam dan struktur sel penyusunnya dengan presentase miskonsepsi sebesar 40,93\%, sedangkan miskonsepsi tertinggi terjadi pada indikator membedakan struktur dan fungsi berbagai jaringan (epidermis, kolenkim, sklerenkim, parenkim, xilem, floem, dan kambium) penyusun organ tumbuhan presentase miskonsepsi sebanyak 46,51\%. Keseluruhan presentase setiap indikator dihitung berdasarkan total miskonsepsi yang terjadi.

\section{Miskonsepsi berdasar Kategori Mahasiswa \\ Tabel 5. Tingkat konsepsi mahasiswa pendidikan biologi berdasarkan kategori kognitif}

\begin{tabular}{lccl}
\hline \multirow{2}{*}{$\begin{array}{c}\text { Kategori } \\
\text { Mahasiswa }\end{array}$} & \multicolumn{3}{c}{ Konsepsi Mahasiswa } \\
\cline { 2 - 4 } & TK & TTK & Mk \\
\hline Bawah & $15,51 \%$ & $25,56 \%$ & $19,07 \%$ \\
\hline Sedang & $55,91 \%$ & $49,15 \%$ & $52,55 \%$ \\
\hline Atas & & & \\
\hline
\end{tabular}

Dari aspek kognitif mahasiswa dapat dipetakan beberapa kategori mahasiswa yaitu bawah, sedang, dan atas. Ketiga kategori mahasiswa ditentukan berdasarkan IPK (Indeks Prestasi Kumulatif) yang diperolah mahasiswa pada semester 1. Semakin tinggi IPK yang diperoleh mahasiswa semakin tinggi kategori mahasiswa tersebut

Dari hasil penelitian yang dilakukan berdasarkan tabel 3 dapat diketahui bahwa miskonsepsi pada mahasiswa pendidikan biologi kategori akademik bawah sebesar 19,07\%, selanjutnya pada kategori akademik atas dengan miskonsepsi sebanyak 28,37\% serta posisi teratas miskonsepsi adalah kategori akademik sedang dengan presentase $52,55 \%$ yang dihitung berdasarkan total mahasiswa yang mengalami miskonsepsi.

\section{PEMBAHASAN}

Analisis pemahaman mahasiswa terhadap materi tersebut didasarkan pada interpretasi hasil pola jawaban mahasiswa pada tes multiple choiche disertai dengan CRI. 
Mahasiswa berada pada kondisi tidak tahu konsep ditandai dengan jawaban salah atau benar namun tingkat keyakinan terhadap jawaban rendah. Hal tersebut dikarenakan kesulitan dalam memahami konsep yang dikerjakan dan alasan yang tidak tepat dalam menjawab konsep materi tersebut sehingga membantu mahasiswa memahami konsep akan meningkatkan keyakinan dalam menyelesaikan persoalan yang diberikan (Mubarak dkk., 2016) Sedangkan tahu konsep merupakan keadaan dimana mahasiswa menjawab pertanyaan dengan benar dan memiliki tingkat keyakinan yang tinggi berkebalikan dengan mahasiswa yang tidak tahu konsep. Tahu konsep dianggap bahwa mahasiswa menguasai materi atau konsep jaringan tumbuhan dengan baik sehingga dalam kategori ini mereka mampu membedakan apa yang diketahui dan tidak diketahui.

Miskonsepsi terjadi berdasarkan analisis jawaban yang diberikan salah namun tingkat keyakinan atas jawaban tersebut tinggi. Miskonsepsi merupakan keadaan dimana jawaban dan gagasan yang diberikan tidak sesuai dengan teori yang dikemukakan oleh para ahli. Masih terdapatnya miskonsepsi pada mahasiswa umumnya terjadi karena kesulitan dalam proses asimilasi konsep baru dengan pengalaman dan perasaan mahasiswa Miskonsepsi dapat pula muncul akibat proses pembelajaran dan pengalaman mahasiswa atau dikarenakan konsep yang diajarkan tidak sesuai dengan perkembangan mental mahasiswa (Mubarak dkk., 2016). Dengan kata lain miskonsepsi dapat bersumber dari dalam diri siswa sendiri, guru, buku teks pelajaran yang digunakan, konteks dan cara yang digunakan guru dalam mengajar (Suparno, 2013). Kesalahan yang terdapat dalam diri siswa sendiri sehingga menjadi penyebab adanya miskonsepsi meliputi reasoning yang tidak lengkap atau salah, intusi yang salah, prakonsepsi yang tidak tepat, serta rendahnya kemampuan mahasiswa dalam materi tersebut.

Persebaran miskonsepsi terjadi pada seluruh indikator yang diujikan disebabkan karena beberapa faktor yang pertama yaitu penggunaan sumber belajar berupa buku teks pelajaran biologi yang ditemukan adanya miskonsepsi. Buku merupakan salah satu faktor yang menyebabkan terjadinya miskonsepsi pada peserta didik (Imanasita dkk., 2013). Apabila konsep yang ada dalam buku teks pelajaran adalah konsep yang salah dan tidak segera diperiksa dan diperbaiki dengan cepat, akan berdampak negatif terhadap proses pemahaman peserta didik sekarang dan selanjutnya (Dikmenli dkk., 2009)

Proses pembelajaran saat SMA dimana guru hanya menjelaskan sebatas materi dasar untuk siswa, selain itu saat menjadi siswa dan sekarang mahasiswa , mereka tidak belajar secara mandiri untuk mendapatkan informasi-informasi mengenai konsep materi secara mendalam, hanya bergantung pada penjelasan guru dan dosen saat perkuliahan. Hal tersebut berdampak pada pengusaaan materi yang kurang optimal pada mahasiswa. Penguasaan konsep yang kurang optimal mengakibatkan miskonsepsi terjadi (Marsita, dkk. 2010). Konsep struktur dan fungsi jaringan tumbuhan adalah salah satu materi yang sulit dipahami disebabkan banyaknya istilah ilmiah yang abstrak dan banyak konsep yang harus dihafal (Murni, 2013). 
Selain itu faktor lain yang mengakibatkan miskonsepsi terjadi pada mahasiswa yaitu usaha mahasiswa yang menjawab soal dengan mencoba menalar dan menghubungkan konsep yang berkaitan akan tetapi penalaran tidak sesuai konsep atau salah disebabkan siswa kurang utuh dalam pemahaman soal tersebut (Suparno, 2013). Penyebab miskonsepsi juga terjadi akibat kesalahan metode atau cara belajar mahasiswa yang hanya menghafal tanpa paham konsep sehingga berdampak pada kesalahan dalam penerimaan informasi (Laily, 2015).

Tingkat kognitif mahasiswa berdasarkan nilai IPK yang diperoleh tidak mempengaruhi miskonsepsi pada materi jaringan tumbuhan. Miskonsepsi disebabkan oleh pengetahuan awal yang salah terhadap materi yang diujikan sehingga pengetahuan awal tersebut menghambat mahasiswa untuk memahami dan mempelajari pengetahuan baru. Kemampuan akademik tidak berpengaruh terhadap pemahaman konsep siswa (Yulianto, 2009). Mahasiswa yang memiliki pengetahuan yang banyak serta relevan dengan konsep atau materi yang diujikan akan lebih paham atau tahu konsep daripada mahasiswa memiliki kategori akademik tinggi namun pengetahuan awal mengenai konsep yang diujikan sedikit.

\section{KESIMPULAN}

Dari hasil penelitian miskonsepsi menggunakan CRI pada materi jaringan tumbuhan yang telah dilakukan dapat disimpulkan bahwa pada mahasiswa pendidikan biologi di salah satu Universitas di Surakarta sebanyak 26,34\% mengalami miskonsepsi, sedangkan pada mahasiswa paham konsep sebanyak $30,02 \%$ serta mahasiswa yang tidak tahu konsep sebanyak $43,62 \%$.

Miskonsepsi tidak terpengaruh oleh kategori akademik mahasiswa hal ini ditunjukkan tingkat miskonsepsi tertinggi berada pada mahasiswa kategori sedang sebesar 52,55\%, diikuti dengan mahasiswa kategori atas $28,37 \%$ dan yang terakhir adalah mahasiswa kategori bawah sebanyak $19,07 \%$.

\section{SARAN}

Miskonsepsi yang terjadi pada siswa perlu cepat diidentifikasi oleh guru, dan komponen sekolah lainnya. Selain dari jenjang SMA miskonsepsi juga perlu diidentifikasi pada jenjang yang lebih rendah bahkan lebih tinggi seperti perguruan tinggi, karena kemungkinan miskonsepsi terjadi pada semua kalangan. Identifikasi harus diikuti dengan langkah lanjutan dari guru maupun instansi terkait yang dapat mengupayakan reduksi miskonsepsi pada pihak-pihak tertentu.

\section{DAFTAR RUJUKAN}

Dahar, R. W. 2011. Teori-Teori Belajar dan Pembelajaran. Jakarta: Erlangga.

Dikmenli, M. O. Cardak \& O. Fulya. 2009. Conceptual Problems in Biology Toples in Primary Science and Technology Texbooks in Turkey. International Journal of Environtment and Science Education, 4(4): p429-440.

Gumilang, R. 2017. Indentifikasi Miskonsepsi Biologi Menggunakan Certainty of Response index (CRI) pada Materi Struktur dan Fungsi Jaringan Tumbuhan Siswa Kelas XI 
IPA SMA N 1 Depok Yogyakarta.

Skripsi. Yogyakarta : Universitas Islam Negeri Sunan Kalijaga Yogyakarta

Imanasita, D., W. Sakti, P. Biologi, Y. Wibowo, \& M. Si. 2013. Identifikasi Miskonsepsi Struktur Fungsi Jaringan Tumbuhan dalam Buku Teks Biologi Sma Kelas XI Kurikulum 2013, 23-30.

Laily, I. 2015. Profil Miskonsepsi Siswa Pada Materi Struktur Dan Fungsi Jaringan Tumbuhan. BioEdu, 4(3): 991-995.

Marsita, R. A, S. Priatmoko, \& E. Kusuma. 2010. Analisis Kesulitan Belajar Kimia Siswa SMA Dalam Memahami Materi Larutan Penyangga dengan Menggunakan Two-Tier Multiple Choice Diagnostic Instrument. Jurnal Inovasi Pendidikan Kimia. 4 (1): 512-520.

Mubarak, S., E. Susilaningsih, \& E. Cahyono. 2016. Pengembangan Tes Diagnostik Three Tier Multiple Choice. Journal of Innovative Science Education, 5(2): 101-110.

Kusumaningrum, R. 2014. Pengaruh Model Guided Discovery Learning Terhadap Miskonsepsi Siswa Kelas XI IPA SMA Muhammadiya 1 Karanganyar pada Konsep Sistem Imun. skripsi.. Surakarta: Universitas Sebelas Maret

Murni, D. 2013. Identifikasi Miskonsepsi Mahasiswa Pada Konsep Substansi Genetika Menggunakan Certainty
Of Response Index (CRI). Prosiding Semirata. Lampung. Fakultas MIPA : Universitas Lampung

Mustaqim, T. A., Z. Zulfiani, \& Y. Herlanti. 2014. Identifikasi Miskonsepsi Siswa dengan Menggunakan Metode Certainty of Response Index (CRI) pada Konsep Fotosintesis dan Respirasi Tumbuhan. Edusains, 6(2): 147152.

Qurrota, A., \& M. Nuswowati. 2018. Analisis miskonsepsi siswa menggunakan tes diagnostic multiple choice berbantuan CRI (Certainty of Response Index), 12(1): 2108-2117.

Ramadhani, R., Hasanuddin., \& Asiah. 2016. Identifikasi Miskonsepsi Siswa pada Konsep Sistem Reproduksi Manusia Kelas XI IPA SMA unggul Ali Hasjmy Kabupaten aceh besar. Jurnal Ilmiah Mahasiswa Pendidikan Biolog. 1(1): 1-9.

Ross, P., D. Tronson, \& J.R. Raymond. 2006. Modelling Photosythesis to Increase Conceptual Understanding Journal of Biological Education, 40(2): 84-88.

Suparno, P. (Eds.). 2013. Miskonsepsi dan Perubahan Konsep dalam Pendidikan Fisika. Jakarta : PT Grasindo

Yulianto \& Rusmiyati. 2009. Peningkatan Keterampilan Proses Sains Dengan Menerapkan Model Problem Based Instruction.Jurnal Pendidikan Fisika Indonesia, 5: 75-78. 